\title{
Prevalence and risk factor analysis for post-partum depression in women: a cross-sectional study at tertiary care centre
}

\author{
Kanchan Rani ${ }^{1 *}$, Nupur Nandi ${ }^{1}$, Seema Singh Parmar ${ }^{2}$, Priyanka Rathore ${ }^{1}$
}

\begin{abstract}
${ }^{1}$ Department of Obstetrics and Gynecology, Teerthankar Mahaveer Medical College, Bagadpur, Moradabad, Uttar Pradesh, India

${ }^{2}$ Department of Psychiatry, Teerthankar Mahaveer Medical College, Bagadpur, Moradabad, Uttar Pradesh, India
\end{abstract}

Received: 28 October 2019

Revised: 19 November 2019

Accepted: 05 December 2019

\section{*Correspondence:}

Dr. Kanchan Rani,

E-mail: drkanchanrani@gmail.com

Copyright: ( $)$ the author(s), publisher and licensee Medip Academy. This is an open-access article distributed under the terms of the Creative Commons Attribution Non-Commercial License, which permits unrestricted non-commercial use, distribution, and reproduction in any medium, provided the original work is properly cited.

\section{ABSTRACT}

Background: Postpartum depression (PPD) is non-psychotic depressive episode that occurs between postpartum to fourteen months of childhood. It has adverse effect on mother and child health. Aim of this study was to analyze prevalence and risk factors for postpartum depression at tertiary care centre.

Methods: This cross-sectional study was done in obstetrics and gynaecology department where 175 women between 10 days to 1 year of delivery were assessed using Edinberg postpartum depression scale. A score of 10 or more were taken as sign of postpartum depression. Various socio-demographic and obstetrics variables were assessed using SPSS (Statistical Package for the Social Sciences).

Results: Prevalence of PPD was found in $11.4 \%$ patients. Common risk factors associated were intrauterine death (IUD) or early neonatal death, postpartum complications and lack of family support.

Conclusions: Postpartum is common among postnatal women and is associated with various factors which can be modified. So early detection of associated risk factors is needed for early intervention and prevents its impact on mother and child health.

Keywords: Depression, Postpartum, Prevalence, Risk factors

\section{INTRODUCTION}

According to American Psychological Association (APA) postpartum depression is defined as "a serious mental health problem characterized by a prolonged period of emotional disturbance occurring at a time of major life change and increased responsibilities in the care of new born". ${ }^{\text {. Post- }}$ partum depression (PPD) is non psychologic depressive episode that occurs after 1st week of postnatal period and can last up to 14 months of child birth. ${ }^{2-5}$ PPD can have pernicious effect on mother and child bonding. ${ }^{6-9}$ It can be detrimental for the offspring and can negatively affect her marital relationship. ${ }^{10,11}$ Undiagnosed and untreated PPD can lead to chronic recurrent depression and interpersonal problems in later life. ${ }^{12}$

Mental health problems of mother in India is most disregarded area. Studies have shown the benefits of early diagnosis and treatment of PPD. ${ }^{13,14}$

So, we conducted a cross sectional study to interview women in postpartum period to assess prevalence of postpartum depression and analyse its risk factors so that early intervention can be done to prevent its impact on women and her children's health and elude its remote consequences. 


\section{METHODS}

A cross sectional analytical study was done in department of obstetrics and gynaecology from December 2018 to August 2019 in Teerthankar Mahaveer Medical College, Moradabad. The present study was approved by Institutional Ethical Committee. Informed consent was obtained from each patient.

\section{Inclusion criteria}

- All post-natal women between 18 to 45 years of age from 10 days to 1 year of delivery willing to participate and giving consent for the study.

\section{Exclusion criteria}

- Women with previous history of mental illness and women on antidepressant and antipsychotics. Women showing symptoms of psychosis and severely sick women not able answer the questionnaire were excluded.

Total 175 women between ten days of delivery to 1 year were selected randomly which were meeting the inclusion criteria.

Instrument used to screen postpartum depression was Edinberg post-partum depression scale validated Hindi version. Edinberg post-partum depression scale enquires about sleep disturbances, crying spells, sadness, hopelessness, suicidal ideation and low self-esteem It consists of 10 questionnaires. Women were given the questionnaire and were asked to mark the most appropriate answer of each question on how they felt during last 7 days. Patients were encouraged to complete the questionnaire on their own with minimum assistance to reduce bias. Responses are scored as 0, 1, 2 and 3 . Score ranges from 0-30. Women who exceeded the threshold score of 10 or more were taken as signs of PPD. ${ }^{15}$ The sociodemographic, obstetrics and various variables regarding delivery and post- natal period and family were asked and noted. Patients showing signs of PPD were referred to psychiatry department for further management.

\section{Statistical analysis}

The data was tabulated in Microsoft excel sheet and analyzed in SPSS version 23.0. Association between post-partum depression and various risk factors were determined by odds-ratio and significant association was accepted at $\mathrm{P}$-value $<0.05$.

\section{RESULTS}

Out of 175 women included in study 20 patients $(11.4 \%)$ scored more than 10 i.e. were found to be depressed on Edinberg Post -partum depression scale. Various factors affecting PPD were compared and represented in tabular form (Table 1).

Table 1: Comparison between depressed and nondepressed group of postnatal women on the basis of the demographical and obstetrical factors.

\begin{tabular}{|c|c|c|c|}
\hline Factors & $\begin{array}{l}\text { Depressed } \\
\text { group n }(\%)\end{array}$ & $\begin{array}{l}\text { Non- } \\
\text { depressed } \\
\text { group } \mathbf{n}(\%)\end{array}$ & $\begin{array}{l}\text { OR }(P- \\
\text { value })\end{array}$ \\
\hline \multicolumn{3}{|l|}{ Age } & \multirow{3}{*}{$\begin{array}{l}0.8675 \\
(0.47)\end{array}$} \\
\hline $18-25$ & 10 & 72 & \\
\hline$\geq 25$ & 10 & 93 & \\
\hline \multicolumn{3}{|c|}{ History of previous abortion } & \multirow{3}{*}{$\begin{array}{l}0.3421 \\
(0.11)\end{array}$} \\
\hline Present & 2 & 38 & \\
\hline Absent & 18 & 117 & \\
\hline \multicolumn{3}{|c|}{ Previous IUD } & \multirow{3}{*}{$\begin{array}{l}0.2748 \\
(0.01)\end{array}$} \\
\hline Present & 8 & 24 & \\
\hline Absent & 12 & 131 & \\
\hline \multicolumn{3}{|c|}{ Mode of delivery } & \multirow{3}{*}{$\begin{array}{l}1.692 \\
(0.19)\end{array}$} \\
\hline Vaginal & 11 & 65 & \\
\hline LSCS & 9 & 90 & \\
\hline \multicolumn{3}{|c|}{ Sex of Baby } & \multirow{3}{*}{$\begin{array}{l}1.373 \\
(0.33)\end{array}$} \\
\hline Male & 9 & 82 & \\
\hline Female & 11 & 73 & \\
\hline \multicolumn{3}{|c|}{ Congenital Malformation of baby } & \multirow{3}{*}{$\mathrm{P}=0.88$} \\
\hline Present & 0 & 1 & \\
\hline Absent & 20 & 154 & \\
\hline \multicolumn{3}{|c|}{ Postpartum complications } & \multirow{3}{*}{$\begin{array}{l}2.862 \\
(0.03)\end{array}$} \\
\hline Present & 7 & 94 & \\
\hline Absent & 13 & 61 & \\
\hline \multicolumn{3}{|c|}{ Family support } & \multirow{3}{*}{$\begin{array}{l}0.295 \\
(0.02)\end{array}$} \\
\hline Present & 4 & 71 & \\
\hline Absent & 16 & 84 & \\
\hline \multicolumn{3}{|c|}{ Condition of baby } & \multirow{4}{*}{$\mathrm{P}<0.001$} \\
\hline MS & 4 & 120 & \\
\hline NICU & 2 & 21 & \\
\hline IUD & 14 & 14 & \\
\hline \multicolumn{3}{|c|}{ Education } & \multirow{3}{*}{$\begin{array}{l}0.623 \\
(0.27)\end{array}$} \\
\hline Illeterate & 5 & 54 & \\
\hline Literate & 15 & 101 & \\
\hline \multicolumn{3}{|l|}{ Parity } & \multirow{3}{*}{$\begin{array}{l}1.036 \\
(0.56)\end{array}$} \\
\hline Primi & 7 & 53 & \\
\hline Multi & 13 & 102 & \\
\hline
\end{tabular}

On evaluating the impact of various factors age was not associated with PPD. History of previous abortion was not associated with PPD but history of previous IUD was seen to be associated with development of PPD ( $\mathrm{p}=$ $0.013)$. Sex of baby was not found to be associated with increased risk of PPD $(\mathrm{P}=0.33)$.

There was less chance of development of PPD in patients having family support. $(\mathrm{P}=0.02)$ Also patient developing postpartum complication showed more chances of developing PPD $(\mathrm{P}=0.03)$. 
PPD was not found to be associated with education (OR $=0.62, \mathrm{P}=0.27)$ or socioeconomic status $(\mathrm{p}=0.09)$. There was no statistically significant difference in women who were housewife or working $(\mathrm{P}=0.3)$. PPD was found to be significantly associated with IUD or early neonatal death $(\mathrm{P}=0.01)$.

\section{DISCUSSION}

Prevalence of PPD in our study is $11.4 \%$. Various studies from India and western countries showed prevalence of PPD in the range of $10-15 \% .{ }^{16-19}$ Prevalence of PPD in a study from Delhi showed $12.75 \% .{ }^{20}$ According to Gupta $\mathrm{S}$ et al prevalence was $15.8 \%$ and $12.5 \%$ according to Desai et al. ${ }^{16,21}$

Prevalence of PPD was higher i.e. $27 \%$ in a study from Mysore. ${ }^{22}$ In our study age was not found to be associated with PPD a, although various studies like a study from Delhi and a study from China have shown association of young age and PPD. ${ }^{20}$ In this study history of previous abortion was not associated with PPD but history of previous IUD has association with PPD. Present study did not show association of PPD with sex of child. This is in contrast with various studies where PPD was seen to be associated with delivery of female child. ${ }^{16,21}$ Patient who developed postpartum complication shows increased chance of developing PPD. In present study who had family support showed less chance of developing PPD. Result of our study was similar to other study like Farheen et al, showed increased feeling of loneliness among depressed postpartum women which could be due to less social and emotional support. ${ }^{20}$ Ray $\mathrm{S}$ et al and Stewart DE et al also showed association between social support and PPD. ${ }^{18,23}$ Our study did not show association between education, socio economic status and working status of women with PPD. PPD was found to be significantly high in women who had either IUD or sick newborn. Patel et al and Szymusik I et al also showed association of PPD with sick babies. ${ }^{24,25}$

Limitations of study was that it was hospital based cross sectional study and does not represent the whole population at risk. This study does not include women from high socio economical group.

\section{CONCLUSION}

Post-partum depression is common among postnatal women which can affect mother child and family as a whole. It is associated with various modifiable factors like family and social support. So early detection of PPD and counselling of women and family as a whole has a big role in its prevention for women at risk.

\section{Funding: No funding sources} Conflict of interest: None declared

Ethical approval: The study was approved by the Institutional Ethics Committee

\section{REFERENCES}

1. American Psychological Association, Post-partum depression. Available at: http://www.apa.org/pi/ women/resources/reports/postpartum-dep.aspx. Accessed on $10^{\text {th }}$ September 2019.

2. Leitch S. Postpartum depression: A review of the literature. St. Thomas, Ontario: Elgin-St. Thomas Health Unit; 2002.

3. Cutrona CE. Social support and stress in the transition to parenthood. J Abnorm Psychol. 1984;93:378-90.

4. Goodman JH. Postpartum depression beyond the early postpartum period. J Obstet Gynecol Neonat Nurs. 2004;33:410-20.

5. Stowe ZN, Nemeroff CB. Women at risk for postpartum-onset major depression. Am J Obstet and Gynecol. 1995;173:639-45.

6. Barnes DL. Postpartum depression: its impact on couples and marital satisfaction. J Syst Ther. 2006;25:25-42.

7. Dennis $\mathrm{C}$, McQueen $\mathrm{K}$. The relationship between infant-feeding outcomes and postpartum depression: a qualitative systematic review. Pediatr. 2009;123:e736-e751.

8. Halbreich U, Karkun S. Cross-cultural and social diversity of prevalence of postpartum depression and depressive symptoms. J Affect Dis. 2006;91:97-111.

9. Mancini F, Carlson C, Albers L. Use of the postpartum depression screening scale in a collaborative obstetric practice. J Midwiferywomen's Health. 2007;52:429-34.

10. Kavanaugh M, Halterman J, Montes G, Epstein M, Hightower AD, Weitzman M. Maternal depressive symptoms are adversely associated with prevention practices and parenting behaviors for preschool children. Ambulatory Pediatr. 2006;6:32-7.

11. Robinson GE, Stewart DE. Postpartum disorders. In: Stotland NL, Stewart DE, editors. Psychological aspects of women's health care: the interface between psychiatry and obstetrics and gynecology. 2nd ed. Washington, DC: American Psychiatric Press, Inc; 2001:117-40.

12. Jacobsen T. Effects of postpartum disorders on parenting and on offspring. In L. J. Miller (Ed.), Postpartum Mood Disorders, Washington, DC.: American Psychiatric Press; 1999:119-139.

13. Lumley J. Attempts to prevent postnatal depression. BMJ. 2005;331:5-6.

14. Manber R, Allen JJ, Morris MM. Alternative treatment for depression: empirical support and relevance to women. J Clin Psyclriatr. 2002;63:62840.

15. Cox JL, Holden JM, Sagovsky R. Detection of postnatal depression. Development of the 10-item Edinburgh postnatal depression scale. Br J Psychiatr. 1987;150:782-6.

16. Gupta S, Kishore J, Mala YM, Ramji S, Aggarwal R. Postpartum depression in north Indian women: 
prevalence and risk factors. J Obstet Gynaecol India. 2013;63(4):223-9.

17. Sheela CN, Venkatesh S. Screening for postnatal depression in tertiary care hospital. J Obstet Gynaecol India. 2016;66(1):72-6.

18. Rai S, Pathak A, Sharma I. Postpartum psychiatric disorders: early diagnosis and management. Indian J Psychiatr. 2015;57(2):S216-21.

19. Lanes A, Kuk JL, Tamim H. Prevalence and characteristics of postpartum depressive symptomatology among Canadian women: a cross sectional study. BMC Public Health. 2011;11:302.

20. Zaidi F, Nigam A, Anjum R, Agarwalla R. Postpartum depression in women: a risk factor analysis. J Clin Diagn Res. 2017;11(8):QC13-QC16.

21. Desai ND, Mehta RY, Ganjiwala J. Study of prevalence and risk factors of postpartum depression. Nat J Med Res. 2012;2(2):194-8.

22. Kumar N, Nagaraj AKM, Koudike U, Majgi SM. Psychiatric morbidity and correlates in postpartum women in a tertiary care hospital. Indian J Psychol Med. 2016;38(4):309-14.
23. Stewart DE, Robertson E, Dennis CL, Grace SL, Wallington T. Postpartum depression: Literature review of risk factors and interventions. Tornato Public Health, 2003. Available at. http://www.who.int/mental_health/prevention/suicid e/lit_review_postpartum_depression.pdf. Accessed on $21^{\text {st }}$ September 2019.

24. Patel S, Wittkowski A, Fox JRE, Wieck A. An exploration of illness beliefs in others with postnatal depression. Midwifery. 2013;29(6):682-9.

25. Szymusik I, Wielgoś M, Horosz E, KosińskaKaczyńska K, et al. Affective disorders in the first week after the delivery: prevalence and risk factors. Ginekol Pol. 2008;79:182-5.

Cite this article as: Rani K, Nandi N, Parmar SS, Rathore P. Prevalence and risk factor analysis postpartum depression in women: a cross-sectional study at tertiary care centre. Int J Reprod Contracept Obstet Gynecol 2020;9:266-9. 